\title{
PHYSICAL ATTRIBUTES OF DISTROFERRIC RED LATOSOL UNDER FOUR EUCALYPT SPECIES OVER THE LONG TERM
}

\author{
Atributos físicos de latossolo vermelho distroférrico sob cobertura a \\ longo prazo de quatro espécies de eucalipto
}

\author{
Rafael Malfitano Braga', Moacir de Souza Dias Junior², \\ Francisco de Assis Braga ${ }^{3}$, Thiago de Paula Protásio ${ }^{4}$
}

\begin{abstract}
Planted forests have been increasingly highlighted in the Brazilian scenario, maintaining status regarding their environmental effects, among them those related with soils. The objectives of this work were to evaluate and to compare the physical attributes of a typic distroferric Red Latosol under Eucalyptus cloeziana, E. grandis, E. Pilularis and Corymbia maculata coverage, 37 years after being planted at the Federal University of Lavras campus. The soil profiles were sampled down to $1 \mathrm{~m}$ depth in order to analyze their particle-size distribution, porosity, structure and water retention. The results were submitted to analysis of variance, Scott-Knott multiple means comparison test, correlations and linear regression. The profiles presented appropriated soil physical conditions to provide good plant development. The bulk density and microporosity increased in depth while the total pore volume, macroporosity and aggregates stability decreased in depth. The soil profiles under $E$. cloeziana and $C$. maculata coverage presented lower density, more pores, are more structured, present lower water retention capability and lower water availability than the soil profiles under $E$. grandis and E. pilularis.
\end{abstract}

Index terms: Soil porosity, soil structure, water retention in soil.

\section{RESUMO}

As florestas plantadas ocupam destaque crescente no cenário nacional, permanecendo a questão sobre os seus efeitos ambientais, dentre eles àqueles relacionados ao solo. No presente trabalho, objetivou-se avaliar e comparar atributos físicos de Latossolo Vermelho distroférrico típico sob cobertura de Eucalyptus cloeziana, E. grandis, E. Pilularis e Corymbia maculata, 37 anos após plantio, no campus da Universidade Federal de Lavras. Os perfis foram amostrados até um metro de profundidade, sendo analisadas textura, porosidade, estrutura e retenção de água. Os resultados foram submetidos a análises de variância, testes de comparação múltipla de médias Scott-Knott, correlação e regressão linear. Os perfis apresentaram condições físicas consideradas adequadas ao bom crescimento das plantas. A densidade e a microporosidade aumentaram em profundidade; o volume total de poros, macroporosidade e a estabilidade de agregados decresceram no perfil. Os perfis sob E. cloeziana e $C$. maculata apresentaram-se menos densos, mais porosos e estruturados, e com menor capacidade de retenção e disponibilidade de água em relação aos perfis sob $E$. grandis e E. pilularis.

Termos para indexação: Porosidade do solo, estrutura do solo, retenção de água no solo.

(Received in february 1, 2013 and approved in april 18, 2013)

\section{INTRODUCTION}

One of the main determinant sof soil quality attributes is its structure; which defined the proportion of the solids and voids and the arrangement of the sand, silt, clay particles in composite particles or granules (HILLEL, 1998). A soil with good physical quality must be stable and the clay particles flocculate able to achieve total porosity and pore size distribution suitable for optimal plant growth and development. Thus, soil quality entails a combination of chemical and physical fertility (HILLEL, 1998).
Physical properties of the soil sare altered with use and management, reflecting on its structure in terms of shape and stability (SILVA et al., 2010). In forest soils, such structural change may affect erosivity and root penetration, however organic matter conversion helps insoil aggregation, thereby improving the bulk density, infiltration capacity, moisture retention and drainage attributes of the soil (FISHER; BINKLEY, 2000). In this context, planted forest may improve help physical attributes of soil and its functions (FONSECA et al.,1993).

\footnotetext{
${ }^{1}$ Universidade Federal de Lavras /UFLA - Departamento de Ciências Florestais/DCF - Cx. P. 3037 - $37200-000$ - Lavras - MG - Brasil rafael.malfitano@hotmail.com

${ }^{2}$ Universidade Federal de Lavras/UFLA - Departamento de Ciência do Solo/DCS - Lavras - MG - Brasil

3Universidade Federal de Viçosa/UFV - Campus de Florestal - Viçosa - MG - Brasil

${ }^{4}$ Universidade Federal de Lavras/UFLA - Departamento de Ciências Florestais/DCF - Lavras - MG - Brasil
} 
The physical quality of the soil may be expressed through several attributes including texture, structure, porosity, bulk density, aggregation (CAVENAGE et al. 1999; MARTINS et al., 2002; SILVA et al. 2005; MENDES; MELLONI; MELLONI; NEVES et al., 2007;MELLONI et al., 2008;FERREIRA, 2010). Porosity is the fraction of soil occupied by air and/or water; defining where the dynamic processes of air, nutrients and soil solutions occurs within the soil profile (HILLEL, 1998). Thus the pore size distribution indicates the hydrophysical behavior of soil (RIBEIRO et al., 2007, LIBARDI, 2010). Soil bulk density expresses the relation between mass of solid and total volume, giving an index of the soil structure (FERREIRA, 2010).

Aggregation is related to particle size distribution, stability of the soil aggregates, and it is affected basically by texture, mineralogical composition, content and quality of organic carbon (HILLEL, 1998). The water retention curves establishes the relation between the matric potential and the respective volumetric water content in soil (REICHARDT, 1990; LIBARDI, 2010), expressing the water storage capacity and supply for plants (DEXTER, 2004). Among the information obtained through the water retention curve, the available water capacity (AWC) is an important property for root growth, chemical reactions, movement and absorption of nutrients (JONG VAN LIER, 2010).

The water content in soil at a determined tension is the result complex action of several factors, like content and mineralogy of the clay fraction, organic matter content, microstructure and soil bulk density. Water retention in low suction is related to the soil structure whileat high tension, the amount of water retained is more dependent on the texture and specific surface of the soil (HILLEL, 1998). Considering the importance of silviculture on contemporary national issue of environmental protection in terms of the preservation of soil and air quality (LIMA, 1996; ASSOCIAÇÃO BRASILEIRA DE PRODUTORES DE FLORESTAS PLANTADAS-ABRAF, 2012), this study aimed to the long term effect of the planting of different eucalypts on a typical distroferric Red Latosoland evaluate the changes in their physicals attributes.

\section{MATERIAL AND METHODS}

This study was carried out at the experimental farm of the Universidade Federal de Lavras - UFLA,
Lavras-MG (21 ${ }^{\circ} 13^{\prime} 40^{\prime \prime S}$ and 44 $\left.57^{\prime} 50^{\prime \prime} \mathrm{W} ; 925 \mathrm{~m}\right)$. The climate of Lavras according to Köppen classification is Cwa with a mean temperature of $20.4^{\circ} \mathrm{C}$ and mean precipitation of $1.460 \mathrm{~mm}$ per annum. The study area consists of experiment of species and procedence of eucalypt (Figure 1), planted in January 1974 by EMBRAPA (MOURA et al., 1980), on a typical distroferric Red Latosol with very clayey texture. The evaluated species were Eucalyptus grandis W. Mill ex Maiden, E. pilularis Sm., E. cloeziana F. Muell and Corymbia maculata (Hook.) K.D.Hill \& L.A.S.Johnson, planted in four parcels of $10 \mathrm{~m} \times 15 \mathrm{~m}$, with 5 Nos x 5 Nos trees with $3 \mathrm{~m} \times 2 \mathrm{~m}$ spacing.

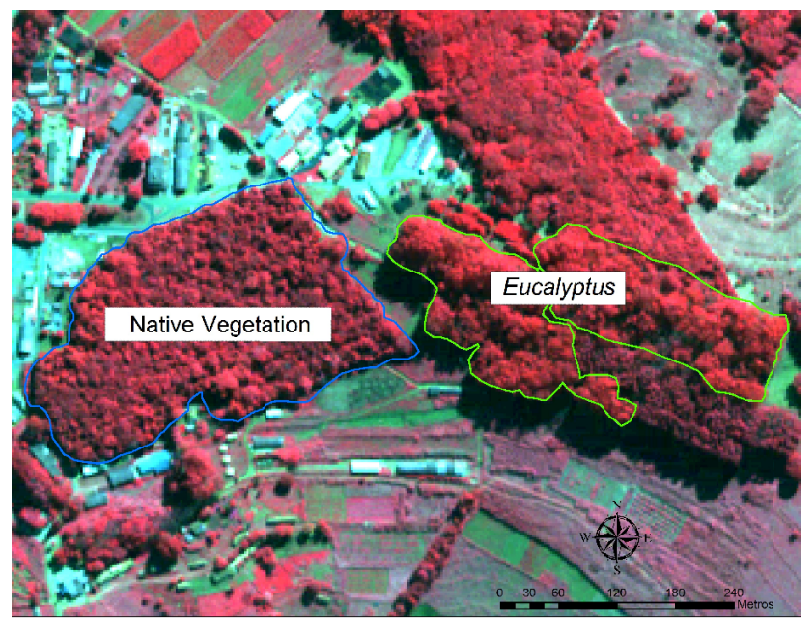

Figure 1 - View of the Eucalypt Experimental Farm of the Federal University of Lavras.

The physical characterization of the soil profile was carried out from undisturbed and disturbed samples collected in the center of each parcels. The undisturbed samples were collected with Uhland sampler in $6.4 \mathrm{~cm} \times 2.54 \mathrm{~cm}$ rings while disturbed samples were collected at places loosed during the sample collection. The samples were collected at seven layers: 0-3, 5-8, 10-13, 15-18, 20-23, 60-63 and 100-103 cm. Sampling was made in January 2011, 37 years after the plots were established.

The analyses on the soil samples included textural classification through the Bouyoucos method (EMPRESA BRASILEIRA DE PESQUISA AGROPECUÁRIA-EMBRAPA, 1997); bulk density in undisturbed samples (BLAKE; HARTGE, 1986a); particles density from volumetric flask (BLAKE; HARTGE, 1986b) and total volume of pores 
(DANIELSON; SUTHERLAND, 1986).The distribution of micro and macropores was determined on undisturbed soil samples using the suction at $60 \mathrm{~cm}$ head water column(GROHMANN, 1960). The aggregates stability in water was determined in samples from $25 \mathrm{~g}$ granules through wet sieving with set of sieves with $5,1.5,0.75,0.375,0.1775$ and 0.0525 mmdiameters immersed in water and shaken for 15 minutes in Yoder mechanical oscillator at a frequency of 32 cycles per minute and a vertical amplitude of $4 \mathrm{~cm}$ (KEMPER; ROSENAU, 1986).After sifting in water, the proportion of each aggregate class was obtained in relation to the total, and the geometric mean diameter (GMD) calculated from the equation:

$$
G M D=10 \frac{\sum_{i=1}^{n}[w i * \log (x i)]}{\sum_{i=1}^{n} w i}
$$

Where wiis the percentage of aggregates in the different sieve classes and $x i$ is the mean diameter of each aggregate class (mm).

The water retention curve was determined in composite, disturbed and homogenized soil samples from layers of $0-20 \mathrm{~cm}$ and $60-100 \mathrm{~cm}$, representing A and B horizons of the profile, and submitted to suctions of 0.002 , $0.004,0.006,0.10,0.033,0.1,0.5$ and 1.5MPa (KLUTE, 1986). The water available capacity (WAC) was calculated as the difference in soil moisture at field capacity (0.006 MPa) (REICHARDT,1988) and permanent wiltin gpoint(1.5 MPa) (KLEIN, 2008). All analyzes were performed at the Soil Physcis laboratory of the department of Soil Science, Universidade Federal de Lavras.

The results of the physical analyses were submitted to variance analysis considering a complete randomized design with a factorial scheme of $4 \times 7$, as the four Eucalypt species, seven depths, with four repetitions. The means were statistically compared by the Scott-Knott test, and the confidence interval determined through $t$ test, at $5 \%$ of significance. Analyzes of simple linear correlation of Pearson were done at $5 \%$ of significance by $t$ test. Linear models were fitted for significant correlations evaluated by $\mathrm{F}$ test (model significance) and by coefficient determination (fitted $\mathrm{R}^{2}$ ).

Data on water retention were analyzed as a complete randomized design, with triple factorial scheme $4 \times 7 \times 2$, as four Eucalypt species, seven suction and two horizons (A and B), with four repetitions. Variance analyzes and tests of multiple comparisons were performed by the statistical software SISVAR (FERREIRA, 2011). Regression and linear correlation analyzes were done by the software R (R DEVELOPMENT CORE TEAM, 2011).

\section{RESULTS AND DISCUSSION}

Result from the analyses of variance indicated that there was no significant alteration between the type of vegetal cover (species)at the different profile depth regarding the behavior of the several studied variables. Therefore only simple and individual effects were evaluated. The various Eucalypt species influenced the soil bulk density, porosity, organic matter content and mean geometric diameter differently. Similarly, the particle density, texture behaved differently at the various studied profiles. While the particles density ranged from 2.51 to $2.58 \mathrm{~g} \mathrm{~cm}^{-3}$, the texture did not vary significantly along the profile characterized typically with high clay content (average of $258 \mathrm{~g} \mathrm{~kg}^{-1}$ of sand, $124 \mathrm{~g} \mathrm{~kg}^{-1}$ of silt and $618 \mathrm{~g} \mathrm{~kg}^{-1}$ ) corresponding toa conditions for it to be considered a typical distroferric Red Latosol (EMBRAPA, 2006).

The species E. cloeziana and $C$. maculate provided similar conditions of a less dense, porous and structured profile, while the soil under E. grandis and $E$. pilularis were denser with high microporosity. Organic matter content in the profiles were similar, except for $C$. maculate plot in which the organic matter contents were lower (Figure 2). The soil bulk density increased along the soil profile indicating an increasing densification of the soil from the 10 to $20 \mathrm{~cm}$ depth (Figure 3 ) as similarly observed by Silva et al.(2005). According to Kiehl (1979), soil bulk density increases with depth due to the overburden pressure exerted by the top layers and the reduction of organic matter content, favoring the densification.

Total porosity, macroporosity, geometric mean diameter and organic matter content also changes throughout the profiles. Microporesproportion increased with depth (Figures 3 and 4), possibly due to the increase in the level of microaggregates commonly associated with the reduction in macrostructure (HILLEL, 1998).

Decrease in GMD with depth was also observed by Wendling et al. (2005) and they attributed this fact to the drying and wetting cycles near at the soil surface. Other possible explanations include the presence of cements agents from the organic residues of eucalypt on the surface which is gradually incorporated into the 
soil (FISHER; BINKLEY, 2000).Several soil physical parameters had been proposed as been optimal for root development and plants growth. Hillel (1998) proposed a porosity range between 0.30 and $0.60 \mathrm{~m}^{3} \mathrm{~m}^{-3}$ and macropore range between 0.06 to $0.20 \mathrm{~m}^{3} \mathrm{~m}^{-3}$. Kiehl (1979) similarly proposed a porosity range between $0.50 \mathrm{~m}^{3} \mathrm{~m}^{-3}$, $1 / 3$ of macropores and 2/3 of micropores. Costa et al. (2006) considered a soil bulk density of $1 \mathrm{~g} \mathrm{~cm}^{-3}$; total porosity of $0.60 \mathrm{~m}^{3} \mathrm{~m}^{-3}$ and available water capacity of $0.13 \mathrm{~m}^{3} \mathrm{~m}^{-3}$. Reichert et al. (2003) proposed soil bulk density between 1.25 and $1.3 \mathrm{~g} \mathrm{~cm}^{-3}$ for very clayey soils. Klein and Libardi (2002) observed that that bulk densities higher than to $1.2 \mathrm{~g} \mathrm{~cm}^{-3}$ reduces soil aeration in Red Latosols. The characteristic optimal value of bulk density forlatosols is approximately $0.95 \mathrm{~g} \mathrm{~cm}^{-3}$ (CAMARGO; ALLEONI, 1997). Considering all these
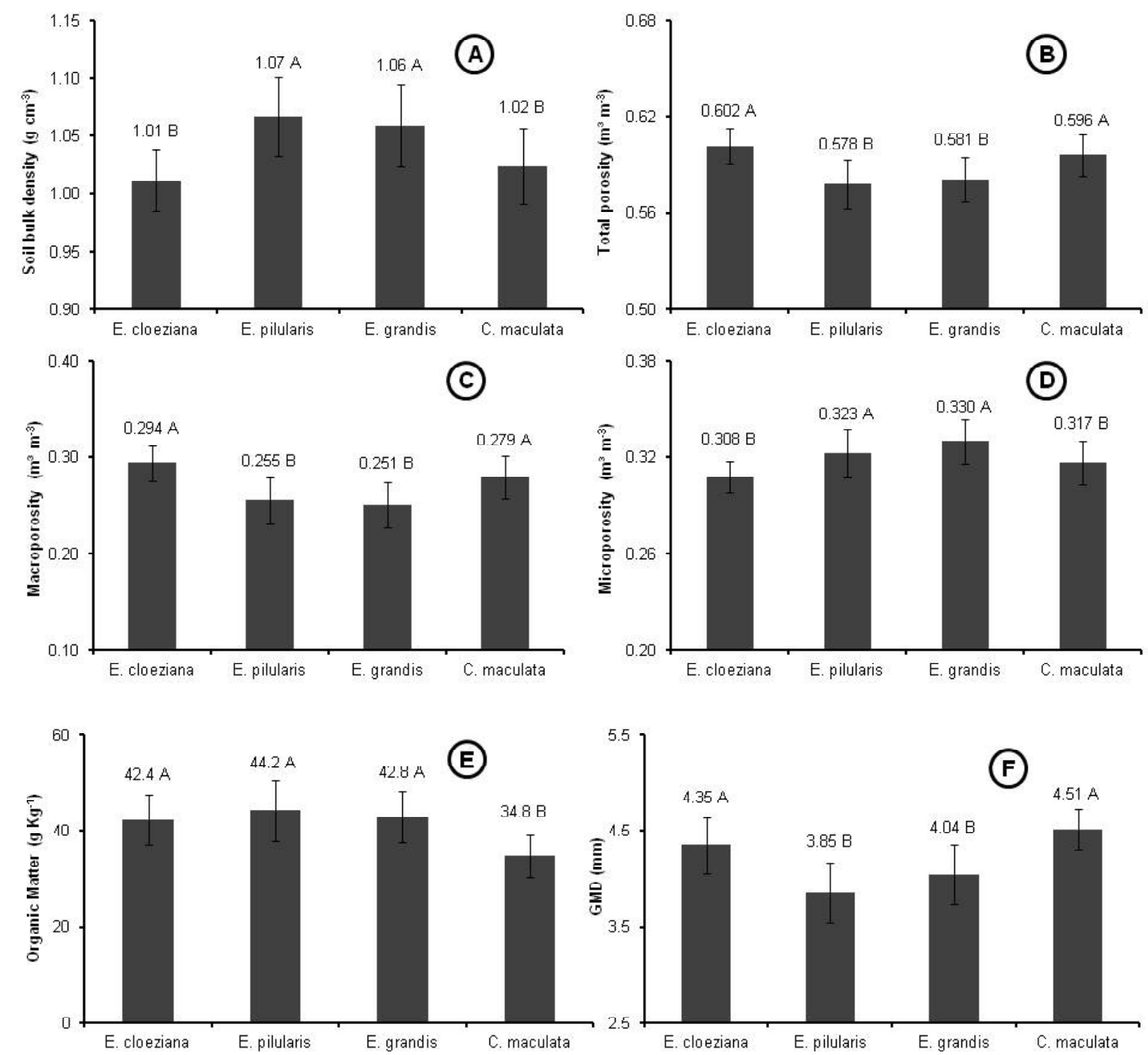

Figure 2 - Properties of soil under different forest species.Soil bulk density (A), total porosity (B), macroporosity (C), microporosity (D), organic matter content (E), mean geometric diameter of aggregates (F). Means followed by the same letter did not differ at $5 \%$ of significance by the Scott-Knott test. Bars indicate the confidence intervals at $5 \%$ of significance by t test.

Ciênc. agrotec., Lavras, v. 37, n. 4, p. 313 - 322, jul./ago., 2013 
references, it is evident that the soils at the studied profiles have adequate physical conditions for the evaluated parameters. Unfavorable soil physical condition was observed by Martins et al. (2002) in the
$0-5 \mathrm{~cm}$ layer of distroferric Red Latosol under 27 years eucalypt. In the study, the GMD was $2.27 \mathrm{~mm}$; micropore of $0.47 \mathrm{~m}^{3} \mathrm{~m}^{-3} ; 0.04 \mathrm{~m}^{3} \mathrm{~m}^{-3}$ macropores and density of $1.27 \mathrm{~g} \mathrm{~cm}^{-3}$.

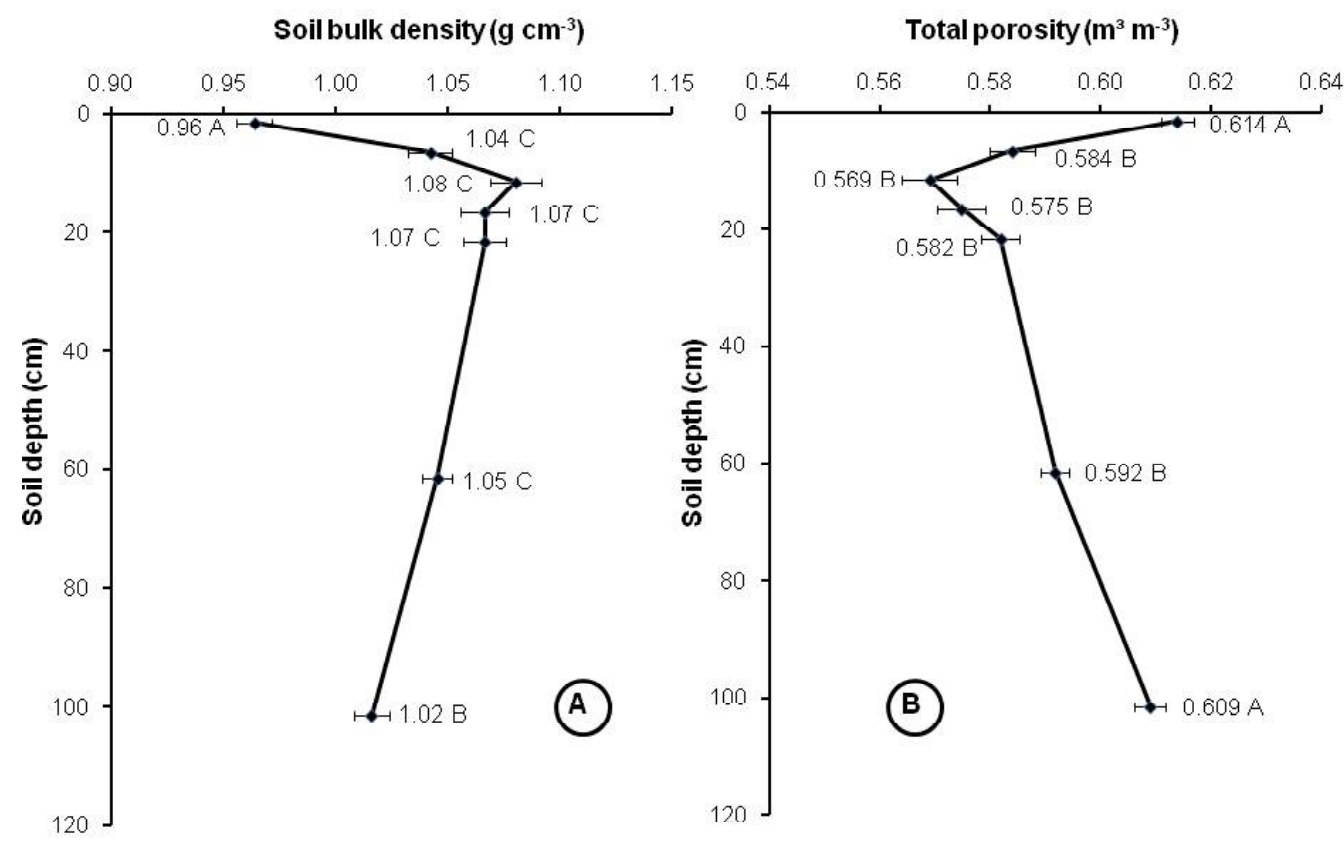

$\operatorname{Macroporosity}\left(\mathbf{m}^{3} \mathbf{m}^{3}\right)$

\section{Microporosity $\left(\mathrm{m}^{3} \mathrm{~m}^{3}\right)$}

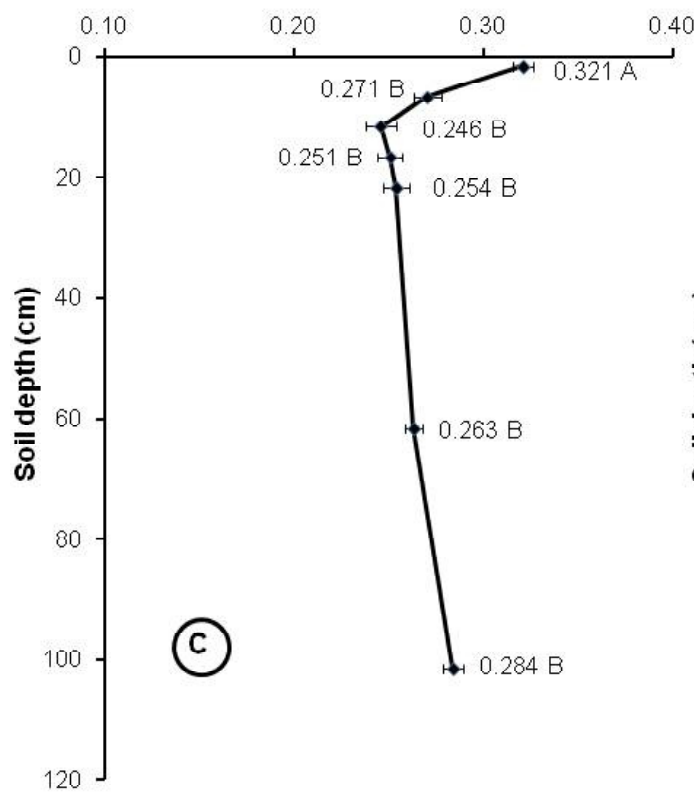

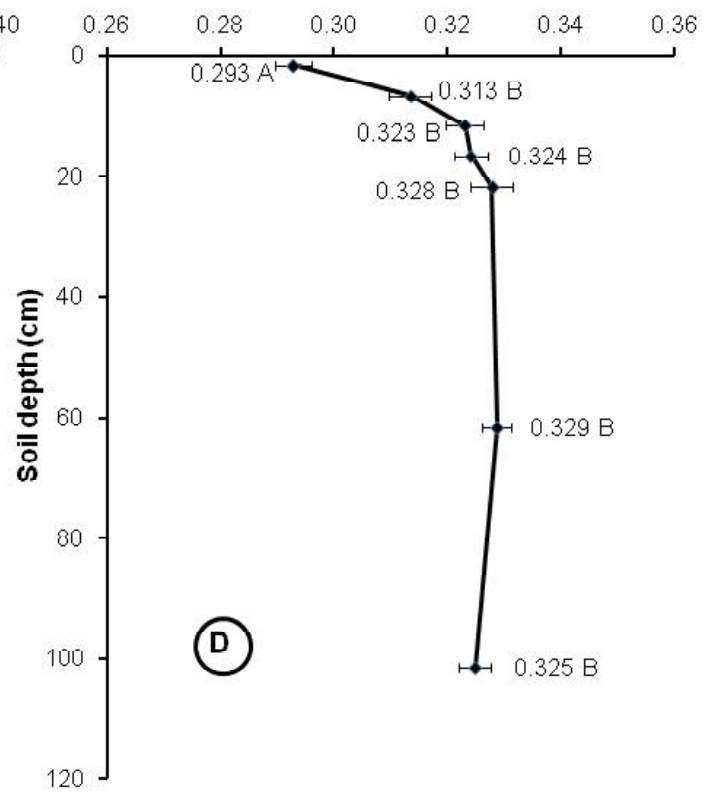

Figure 3 - Pattern of soil bulk density (A), total porosity (B), macroporosity (C), microporosity (D) along the soil profile. Means followed by the same letter did not differ at $5 \%$ of significance by Scott-Knott test. Bars indicate confidence intervals at $5 \%$ of significance by t test. 


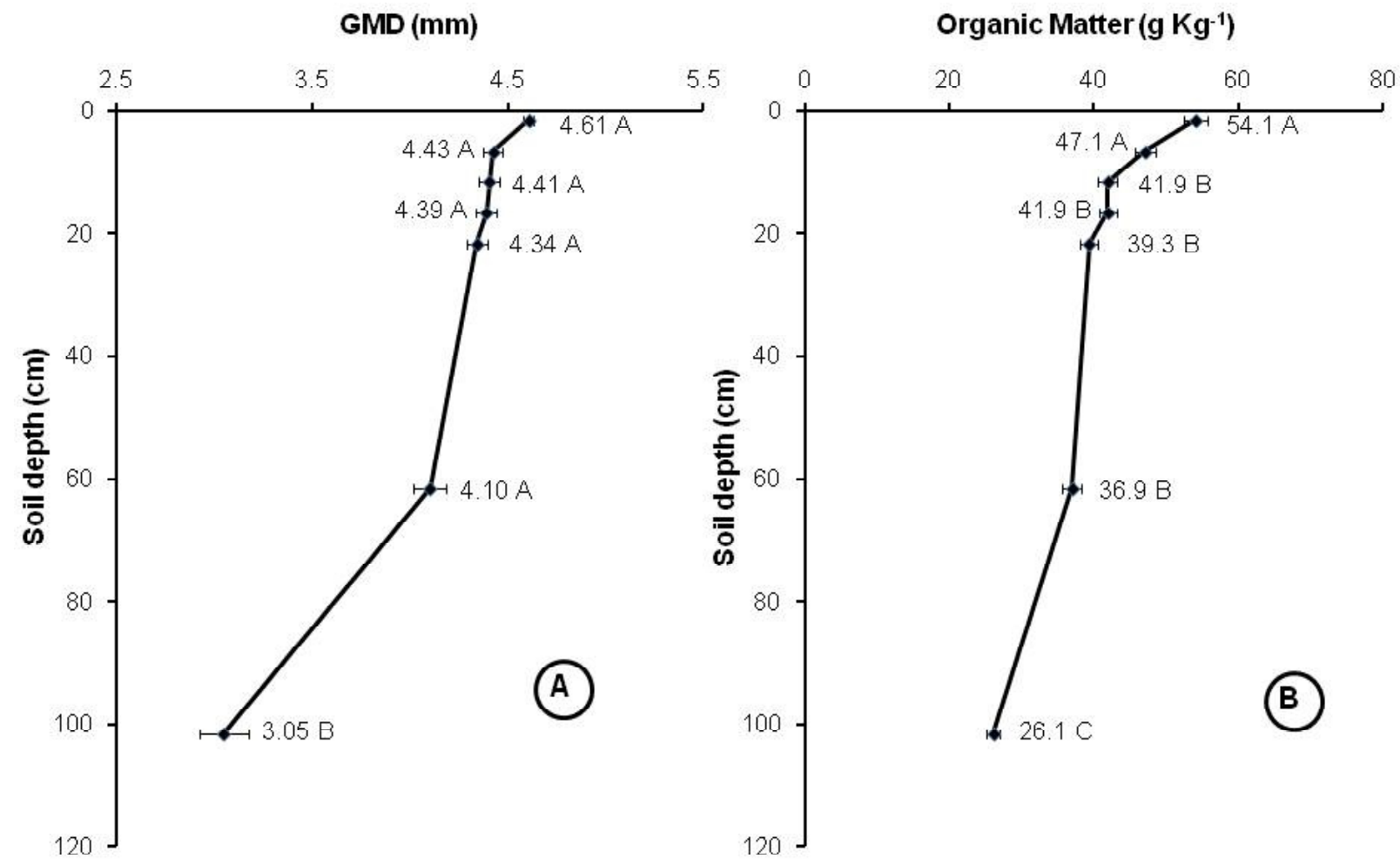

Figure 4 - Pattern of mean geometric diameter of aggregates (A), organic matter content (B) along the studied profile. Means followed by the same letter did not differ at $5 \%$ of significance by Scott-Knott test. Bars indicate confidence intervals at $5 \%$ of significance by $t$ test.

Linear correlation analyses indicated a strong negative relationship between soil bulk density, total porosity and macroporosity, and weak linear relationship with microporosity. Total porosity had high linear correlation with macroporosity and weak inverse relationship with microporosity (Figure 5). This shows that the structure (total porosity) of soil is more associated to macropores, in which case, an increase in bulk density implies a decrease of themacroporosity and increase of microporosity. Linear relationships between macroporosity and soil bulk density, and inverse relationship with microporosity was also observed by Cavenage et al. (1999).

The GMD was weakly related to the organic matter content (correlation $=0.4$ ), showing that size and aggregates stability were littly affected by this factor. Corroborating this fact, higher values of GMD were observed in the soil under C. maculata, species that had the lowest organic matter contents in the profiles (Figure 4). It is important to note that besides organic matter content, e soil aggregation may be influenced by several other factors, like the clay content, polyvalent metals, calcium carbonate, oxides and hydroxides of iron, aluminum and manganese, organic exudates of plants and organic substances provided from the action of microorganisms and wetting and drying cycles of the soil (BASTOS et al., 2005).

The observed high values of GMD (3.85-4.51mm) for the soil with the different eucalyptus species (Figure $2 \mathrm{~F}$ ), and between 3.05 and $4.61 \mathrm{~mm}$ in the studied profiles (Figure 4A) indicate a stable condition and low erodibility of the soil (SILVA et al., 2010).

There were no significant differences in water retention capacity between the A and B horizons as shown in the analyses of variance result. This indicated homogeneity along the profile, typical of latosols (EMBRAPA, 2006). The interaction between the different Eucalypt species and the various soil horizons sampled was also not significant, signaling similarity in the created conditions in the soil profiles with the difference species. On the other hand, we detected that the varied 
Eucalypt species influences water retention capacities in the soil profile, with mean water retention by species following the order: E. pilularis $>$ E. grandis $>C$. maculata $>$ E. cloeziana (Figure 6). In terms of available water capacity (AWC), the order was $E$. grandis $=E$. pilularis $>$ E. cloeziana $=C$. maculata $($ Table 1$)$. The lowest values of available water capacityin the profiles under E. cloeziana and C. maculate may be related to the lowest organic matter contents, micropore volume, and higher soil bulk densities, when compared to the other two species (Figure 1).It is important to highlight that the water retention is determined mainly by the texture, structure, porosity and soil bulk density, and it is less affected by organic matter content (OLNESS; ARCHER, 2005; REICHERT et al., 2009; JONG VANLIER, 2010; BRAIDA et al., 2011). Our result is indicative of the fact that, land use may influence the behavior of Latosol along the profile.
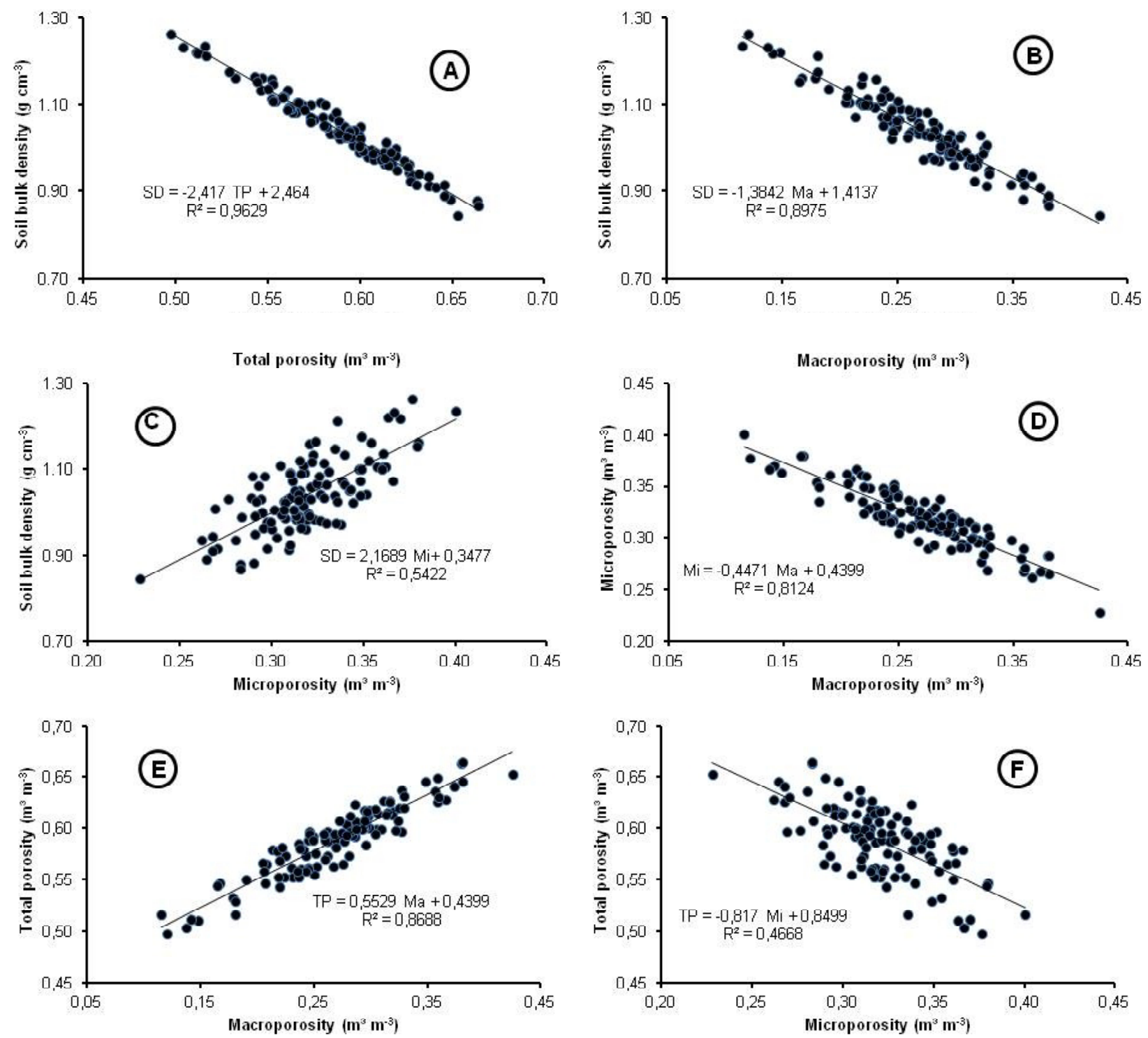

Figure 5 - Relationship between soil bulk density and total porosity (A), soil bulk density and macroporosity (B), soil bulk density and microporosity (C), as well as between microporosity and macroporosity (D), total porosity and macroporosity (E), and total porosity and microporosity $(\mathrm{F})$. 


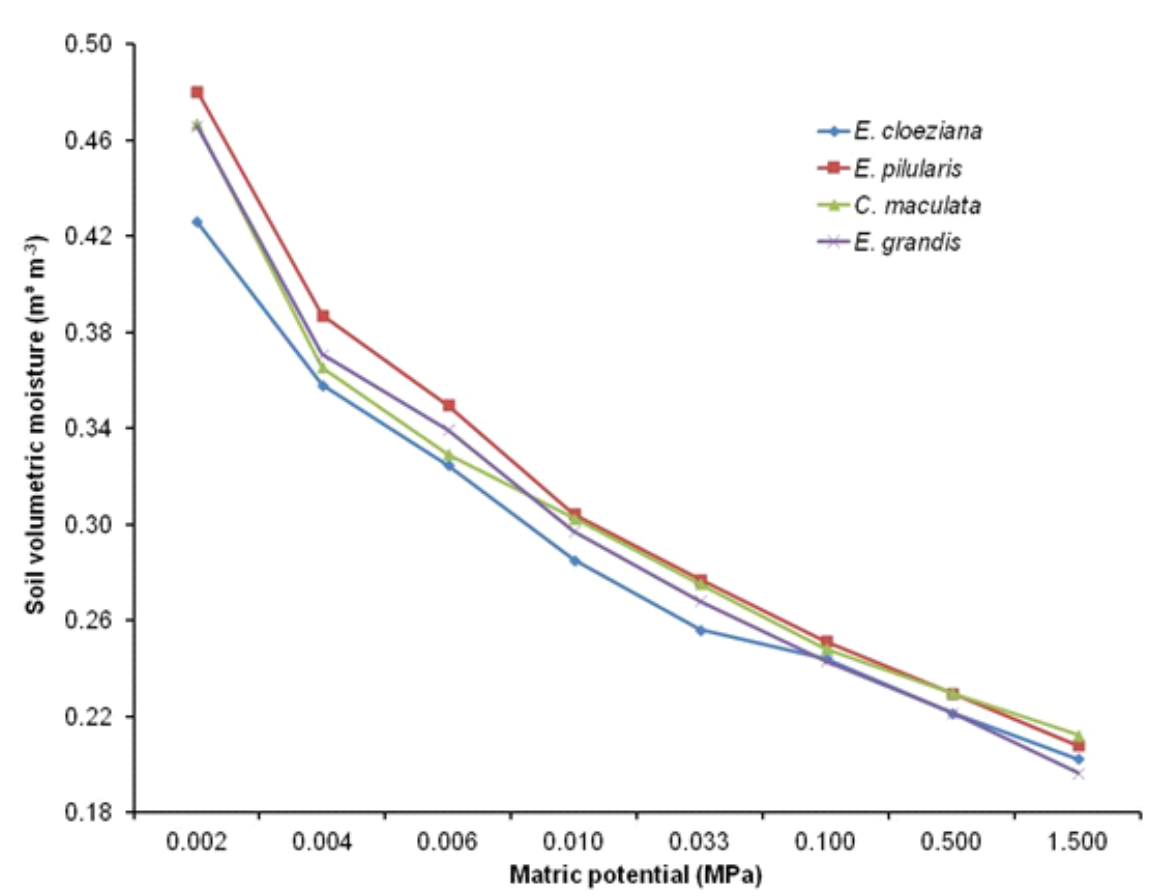

Figure 6-Mean curves of water retention in the protıle for difterent forest species.

Table 1 - Mean values of available water capacity up to one meter deep in the soil for different forest species.

\begin{tabular}{cccc}
\hline & \multicolumn{2}{c}{ Forest Species } & C. maculata \\
\hline E. grandis & E. pilularis & E. cloeziana & \\
$0.1430 \mathrm{~A}$ & Available Water Capacity $\left(\mathrm{m}^{3} \mathrm{~m}^{-3}\right)$ & $0.1170 \mathrm{~B}$ \\
\hline
\end{tabular}

Means followed by the same letter did not differ at $5 \%$ of significance by Scott-Knott test.

\section{CONCLUSIONS}

The soil hydrophysical behavior may be influenced by the land use pattern. We observed that soil profiles under E. cloeziana and C. maculate had the lowest range of bulk densities, available water capacity, besides being more porous and structured than E. grandis and E. pilularis.

Generally, from the studied profiles, it was clear that the growth of the eucalypt ensured adequate hydrophysical condition for optimum plant growth. Also soil bulk density and macroporosity was observed to increase with depth, while the total porosity and macroporosity decrease in the soil profiles.

\section{ACKNOWLEDGEMENTS}

The authors would like to thank the Fapemig, CNPq, Capes for funding this work.

\section{REFERENCES}

\section{ASSOCIAÇÃOBRASILEIRA DE PRODUTORES DE} FLORESTAS PLANTADAS-ABRAF. Anuário estatístico da ABRAF 2012; ano base 2011. Brasília: ABRAF, 2012. 150p.

BASTOS, R. S. et al. Formação e estabilização de agregados do solo influenciados por ciclos de umedecimento e secagem após adição de compostos orgânicos com diferentes características hidrofóbicas.

Revista Brasileira de Ciência do Solo, Viçosa, v.29, n.1, p.21-31, 2005.

BLAKE, G. R.; HARTGE, K. H. Bulk density. In: KLUTE, A. (ed.). Methods of soil analysis. 2 ed. Madison: American Society of Agronomy. v.1, 1986a, p.363-375. 
BLAKE, G. R.; HARTGE, K. H. Partycle density. In: KLUTE, A. (ed.). Methods of soil analysis. 2 ed. Madison: American Society of Agronomy. v.1, 1986b, p.377-382.

BRAIDA, J. A. et al. Matéria orgânica e seu efeito na física do solo. Tópicos em Ciência do Solo, Viçosa, v.7, p.221-278, 2011.

CAMARGO, O. T.; ALLEONI, L. R. F. Compactação do solo e o desenvolvimento das plantas. Piracicaba: ESALQ/USP. 1997, 132p.

CAVENAGE, A. MORAES M. L. T. et al. Alterações nas propriedades físicas de um Latossolo Vermelho-Escuro sob diferentes culturas. Revista Brasileira de Ciência do Solo, Viçosa, v.23, n.4, p. 997-1003, 1999.

COSTA, E. A.; GOEDERT, W. J.; SOUSA, D. M. G. Qualidade de solo submetido a dois sistemas de cultivo: preparo convencional e plantio direto. Pesquisa Agropecuária Brasileira, Brasília, v.41, n.7, p.1185-1191, 2006.

DANIELSON, R. E.; SUTHERLAND, P. L. Porosity. In: KLUTE, A. (ed.). Methods of soil analysis. 2 ed. Madison: American Society of Agronomy. v.1, 1986, p.443-461.

DEXTER, A. R. Soil physical quality. Part I. Theory, effects of soil texture, density, and organic matter, and effects on root. Geoderma, Amsterdam, v.20, n.3-4, p.201-214, 2004.

\section{EMPRESA BRASILEIRA DE PESQUISA} AGROPECUÁRIA - EMBRAPA. Centro Nacional de Pesquisa de Solos. Manual de métodos de análise de solos. 2 ed. Rio de Janeiro: EMBRAPA, 1997, 212p.

EMBRAPA. Centro Nacional de Pesquisa de Solos. Sistema brasileiro de classificação de solos. 2.ed. Rio de Janeiro: Ministério da Agricultura e do Abastecimento, 2006, 306p.

FERREIRA, D. F. SISVAR: a computer statistical analysis system. Ciência e Agrotecnologia, Lavras, v.35, n.6, p.1039-1042, 2011.

FERREIRA, M. M. Caracterização física do solo. In: JONG VAN LIER, Q. (Org.). Física do Solo. Viçosa: Sociedade Brasileira de Ciência do Solo, p.1-27, 2010.
FISHER, R. F., BINKLEY, D. Ecology and management of forest soils. 3 ed. Wiley, 2000, 489 p.

FONSECA, S. et al. Alterações em um latossolo sob eucalipto, mata natural e pastagem I. Propriedades físicas e químicas. Revista Árvore, Viçosa, v.17, n.3, p.271-288, 1993.

GROHMANN, F. Distribuição do tamanho de poros em três tipos de solo do estado de São Paulo. Bragantia. Campinas: v.73, n.2. p.319-328, 1960.

HILLEL, D. Environmental soil physics. San Diego: Academic Press, 1998, 771p.

JONG VAN LIER, Q. Disponibilidade de água às plantas. In: JONG VAN LIER, Q. (Org.). Física do Solo. Viçosa: Sociedade Brasileira de Ciência do Solo, p.283-298, 2010.

KEMPER, W. D.; ROSENAU, R. C. Aggregate stability and size distribution. In: KLUTE, A. (ed.). Methods of soil analysis. 2 ed. Madison: American Society of Agronomy. v.1, 1986, p. 425-442.

KIEHL, E. J. Manual de edafologia: relações solo-planta. São Paulo: Agronômica Ceres, 1979, 262p.

KLEIN, V. A. Física do solo. Passo Fundo: Ed.

Universidade de Passo Fundo, 2008, 212p.

LEIN, V. A.; LIBARDI, P. L. Densidade e distribuição do diâmetro dos poros de um Latossolo Vermelho, sob diferentes sistemas de uso e manejo. Revista Brasileira de Ciência do Solo, Viçosa, v.26, n.4, p.857-867, 2002.

KLUTE, A. Water retention: laboratory methods. In: KLUTE, A. (ed.). Methods of soil analysis. 2.ed. Madison: American Society of Agronomy, v.1, 1986, p.635-686.

LIBARDI, P. L. Água no solo. In: JONG VAN LIER, Q. (Org.). Física do solo. Viçosa: Sociedade Brasileira de Ciência do Solo, p.103-152, 2010.

LIMA, W. P. Impacto ambiental do eucalipto. 2. ed. São Paulo: EDUSP, 1996, 302 p.

MARTINS, S. G. et al. Avaliação de atributos físicos de um Latossolo Vermelho distroférrico sob diferentes povoamentos florestais. Cerne, Lavras, v.8, n.1, p.32-41, 2002. 
MELLONI, R. et al. Avaliação da qualidade de solos sob diferentes coberturas florestais e de pastagem no sul de Minas Gerais. Revista Brasileira de Ciência do Solo, Viçosa, v.32, n.6, p.2461-2470, 2008.

MENDES, F. G.; MELLONI, E. G P.; MELLONI, R. Aplicações de atributos físicos do solo no estudo da qualidade de áreas impactadas, em Itajubá/MG. Cerne, Lavras, v.12, n.3, p.211-220, 2006.

MOURA, V. P. G. et al. Avaliação de espécies e procedências de Eucalyptus em Minas Gerais e Espírito Santo: resultados parciais. Boletim de pesquisa. EMBRAPA/CPAC, Brasília: p.1-104, 1980.

NEVES, C. M. N. et al. Atributos indicadores da qualidade do solo em sistema agrossilvopastoril no noroeste do estado de Minas Gerais. ScientiaForestalis, Piracicaba, v.74, n.2, p.45-53, 2007.

OLNESS, A.; ARCHER, D. Effect of organic carbon on available water in soil. Soil Science, New Brunswick, v.170, n.1, p.90-101, 2005.

\section{RDEVELOPMENT CORE TEAM.R:A language and} environment for statistical computing.Vienna, Austria: $R$ Foundation for StatisticalComputing, 2011. Disponível em: <http://www.R-project.org>. Acesso em: 04 mar, 2012.

REICHARDT, K. Capacidade de campo. Revista Brasileira de Ciência doSolo, Viçosa, v.12, n.13, p.211216, 1988.
REICHARDT, K. A água em sistemas agrícolas. São Paulo: Manole, 1990, 188p.

REICHERT, J. M.; REINERT, J. M.; BRAIDA, J. A. Qualidade dos solos e sustentabilidade de sistemas agrícolas. Ciência \& Ambiente, Santa Maria, v.27, n.1, p.29-48, 2003.

REICHERT, J. M. et al. Estimation of water retention and availability for Rio Grande do Sul soils. Revista Brasileira de Ciência do Solo, Viçosa, v.33, n.6, p.15471560, 2009.

RIBEIRO, K. D. et al. Propriedades físicas do solo influenciadas pela distribuição de poros, de seis classes de solos da região de Lavras-MG. Ciência e

Agrotecnologia, Lavras, v.31, n.4, p.1167-1175, 2007.

SILVA, A. P. et al. Indicadores da qualidade física do solo. In: JONG VAN LIER, Q. (Org.). Física do Solo. Viçosa: Sociedade Brasileira de Ciência do Solo, p.241282,2010 .

SILVA, R. R.; SILVA, M. L. N.; FERREIRA, M. M. Atributos físicos indicadores da qualidade do solo sob sistemas de manejo na bacia do alto do rio Grande - MG Ciência e Agrotecnologia, Lavras, v.29, n.4, p.719-730, 2005.

WENDLING, B. et al. Carbono orgânico e estabilidade de agregados de um Latossolo Vermelho sob diferentes manejos. Pesquisa Agropecuária Brasileira, Brasília, v.40, n.5, p.487-494, 2005. 